THE RING 31, 1 (2009) DOI 10.2478/v10050-008-0048-4

\title{
AUTUMN PASSAGE OF WADERS (Charadrii) IN THE MIDDLE VISTULA VALLEY (KALISZANY, CENTRAL POLAND)
}

\author{
Grzegorz Grzywaczewski, Jarosław Wiącek and Marcin Polak
}

\begin{abstract}
Grzywaczewski G., Wiącek J., Polak M. 2009. Autumn passage of waders (Charadrii) in the middle Vistula valley (Kaliszany, central Poland). Ring 31, 1: 53-64.

The phenology and dynamics of wader migration were studied at a stopover area in the middle Vistula Valley (Kaliszany ringing station, $51^{\circ} 05^{\prime} \mathrm{N}, 21^{\circ} 48^{\prime} \mathrm{E}$, central Poland). The study was conducted during autumn passage seasons of 1993-1996 and 1999-2001. At this time 364 counts were done from mid-July to the end of October. Altogether 23030 waders of 27 species were recorded within the study period. The most numerous species observed were: the Northern Lapwing (Vanellus vanellus) - 49\% of all birds, Common Sandpiper (Actitis hypoleucos) - 16\% and Greenshank (Tringa nebularia) - 9\%. Species constituting ca 2-4\% of all noted waders each were: the Dunlin (Calidris alpina), Spotted Redshank (T. erythropus), Wood Sandpiper (T. glareola), Curlew (Numenius arquata), Ruff (Philomachus pugnax) and Green Sandpiper (T. ochropus). The proportion of the remaining species did not exceed $2 \%$. The pattern of autumn migration dynamics is presented for the dominant species.
\end{abstract}

G. Grzywaczewski, Department of Zoology, University of Life Sciences, Akademicka 13, PL-20-950 Lublin, Poland, E-mail: grzegorz.grzywaczewski@up.lublin.pl; J. Wiącek, M. Polak, Department of Nature Conservation, Maria Curie-Skłodowska University, Akademicka 19, PL-20-033 Lublin, Poland, E-mail: mpolak@hektor.umcs.lublin.pl

Key words: waders, Charadrii, middle Vistula river, migration, phenology

\section{INTRODUCTION}

Quantifying the patterns of bird migration over space and time has been a useful tool to gain insights into many aspects of migration ecology. Results from these observations could be a basis for more detailed studies on the migrational strategies of waders. The intensive studies on wader migration in Poland concentrated mainly on the Baltic Sea coast (Meissner and Sikora 1995; Gromadzka 1998; Meissner and Ściborski 2002; Meissner 2005, 2006, 2007a, 2007b; Meissner and Huzarski 2006; Meissner and Strzałkowska 2006). Present information concerning inland migration 
of waders through Poland is rather poor and more data from new sites are essential to fulfill gaps in the knowledge of inland wader passage in this part of Europe (Ściborski et al. 2005). The main aim of this research is to study the phenology and dynamics of the wader migration at a stopover area in the middle Vistula Valley near village Kaliszany. Our data are presented and compared with other intensive studies on waders conducted on the Baltic coast in the Gulf of Gdańsk region (Meissner and Sikora 1995, Gromadzka 1998) and at various inland sites of Poland (Luniak 1971, Kunysz and Hordowski 1992, Stawarczyk et al. 1996, Zieliński and Studziński 1996, Dyrcz et al. 1998, Mitrus et al. 1998a, Polakowski and Juniewicz 1998, Kruszyk and Zbroński 2002, Wiehle et al. 2002, Bocheński et al. 2006, Kozik 2006).

\section{MATERIAL AND METHODS}

The study was conducted during autumn passage seasons of 1993-1996 and $1999-2001$ in the middle Vistula valley near village Kaliszany $\left(21^{\circ} 48^{\prime} \mathrm{E}, 51^{\circ} 05^{\prime} \mathrm{N}\right.$, Lublin region, central Poland, Fig. 1). The Vistula is Poland's longest river $-1068 \mathrm{~km}$ from its source on the slopes of Barania Góra to its mouth on the Baltic coast. In the Lublin region the Vistula is of a distinct gap character and is treated as a separate geographic region - the Małopolska Vistula Gap (Kondracki 2001). The width of the valley in this section ranges from 2 to $8 \mathrm{~km}$. The valley is mostly covered by arable fields, orchards, meadows and pastures. The landscape along the Vistula shows heterogenic structure with old river-beds and poplar-willow and elm-ash riverside carrs. The study area includes the natural sandy islets located in $1 \mathrm{~km}$ long section of the river-bed. More detailed description of the study area and the methods of the fieldwork were given in the previous paper (Grzywaczewski et al. 1998). Birds were irregularly observed during the whole day and regularly counted one hour before sunset. The fieldwork lasted from mid-July to the end of October. The numbers of controls in subsequent months were: July - 45, August - 173, September - 92, October - 54. In 1993, 8 counts were done and in $1994-56,1995-49,1996-42,1999-76,2000-84,2001-49$. In total, within

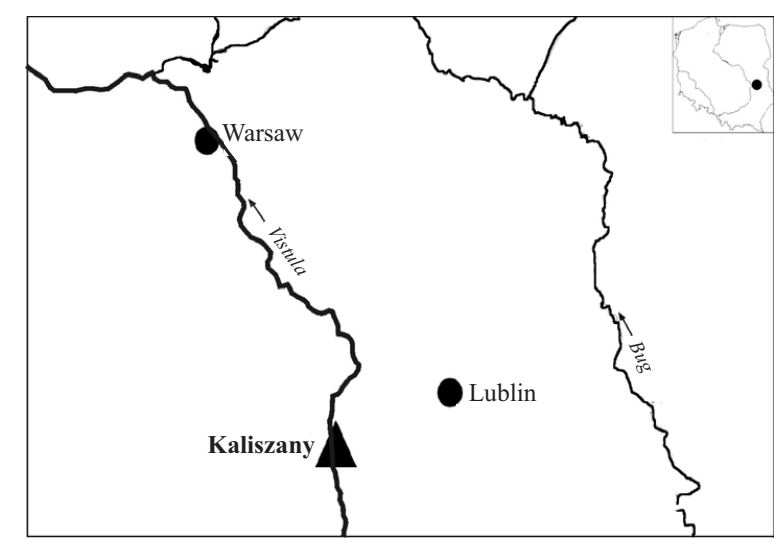

Fig. 1. Location of the study area 
the whole study period, material from 364 days of observation was collected. Counts were made with the use of telescopes $20-60 \times 60$ and binoculars $8-10 \times 50$. For the analysis, the maximum number of birds recorded during a particular day was used. Migration dynamics was shown as the mean sum and the maximal daily number per pentade (five-day period).

\section{RESULTS}

Altogether 23030 waders of 27 species were counted during the study period. The Lapwing (Vanellus vanellus) was the commonest wader (11 266 indiv.), representing $49 \%$ of all the birds (Table 1). The Common Sandpiper (Actitis hypoleucos) made up $16 \%$ of all waders (3779 indiv.). Large numbers of the Greenshank (Tringa nebularia) -

Table 1

Species domination structure and numbers of waders recorded during autumn migration at the Kaliszany station

\begin{tabular}{|c|c|c|}
\hline & Total & Dominance $(\%)$ \\
\hline Vanellus vanellus & 11266 & 48.9 \\
\hline Actitis hypoleucos & 3779 & 16.4 \\
\hline Tringa nebularia & 2016 & 8.8 \\
\hline Calidris alpina & 971 & 4.2 \\
\hline Tringa erythropus & 945 & 4.1 \\
\hline Tringa glareola & 760 & 3.3 \\
\hline Numenius arquata & 567 & 2.5 \\
\hline Philomachus pugnax & 548 & 2.4 \\
\hline Tringa ochropus & 369 & 1.6 \\
\hline Charadrius hiaticula & 321 & 1.4 \\
\hline Charadrius dubius & 315 & 1.4 \\
\hline Gallinago gallinago & 304 & 1.3 \\
\hline Calidris ferruginea & 259 & 1.1 \\
\hline Calidris minuta & 204 & 0.9 \\
\hline Pluvialis squatarola & 103 & 0.4 \\
\hline Calidris temminckii & 79 & 0.3 \\
\hline Tringa totanus & 65 & 0.3 \\
\hline Limosa limosa & 30 & 0.1 \\
\hline Pluvialis apricaria & 26 & 0.1 \\
\hline Calidris canutus & 26 & 0.1 \\
\hline Numenius phaeopus & 18 & 0.1 \\
\hline Haematopus ostralegus & 16 & 0.1 \\
\hline Calidris alba & 14 & 0.1 \\
\hline Tringa stagnatilis & 10 & $<0.1$ \\
\hline Limicola falcinellus & 8 & $<0.1$ \\
\hline Arenaria interpress & 7 & $<0.1$ \\
\hline Scolopax rusticola & 4 & $<0.1$ \\
\hline Total & 23030 & 100.0 \\
\hline
\end{tabular}



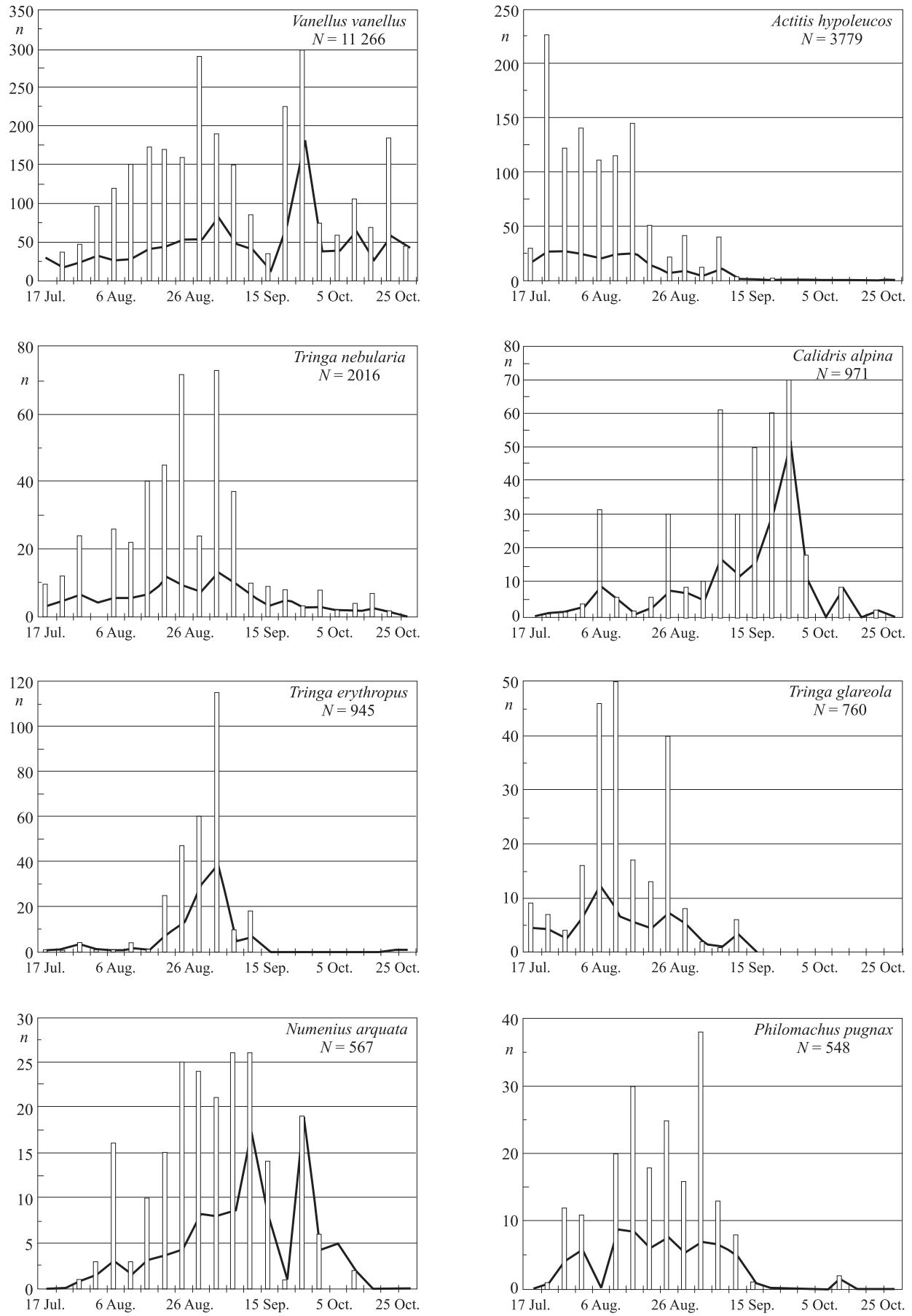

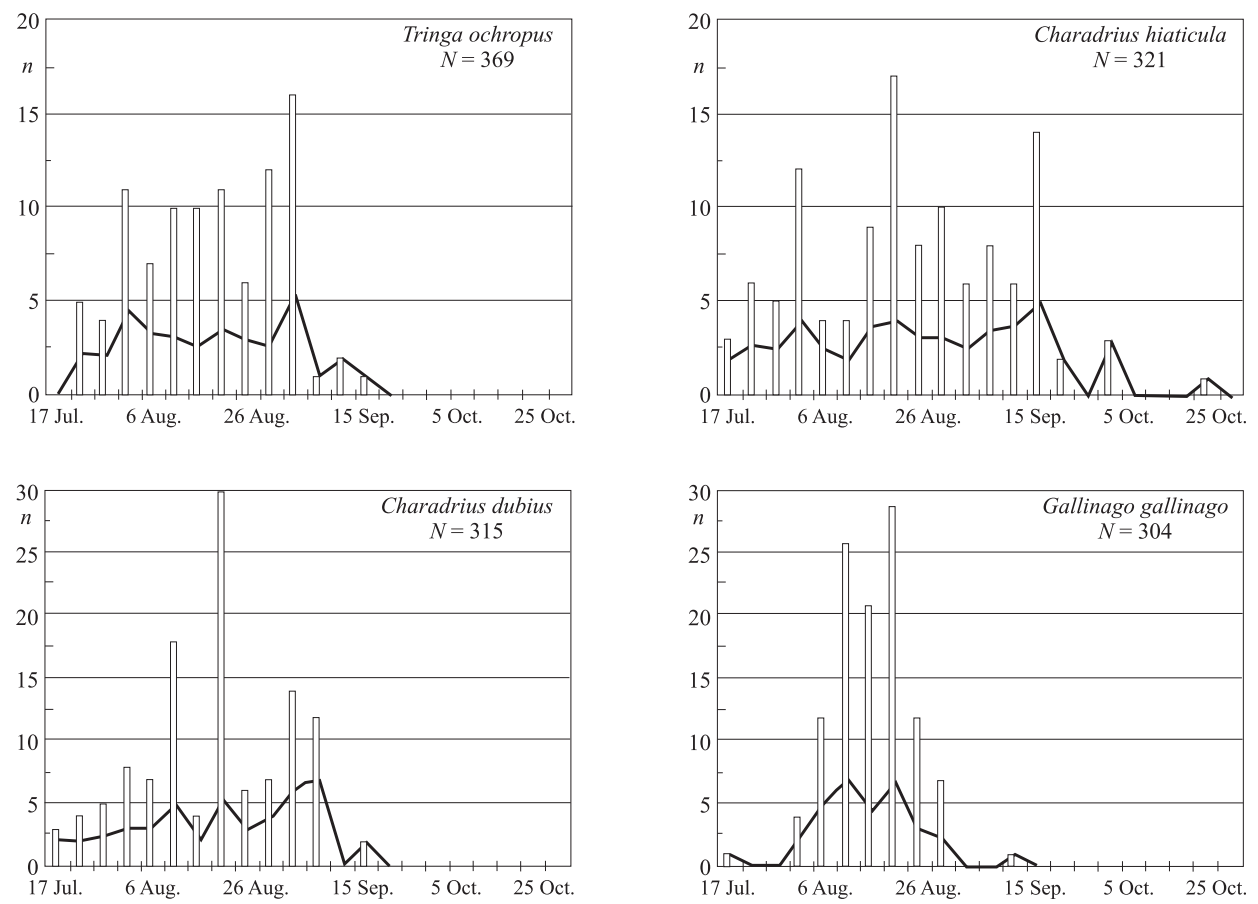

Fig. 2. Autumn migration dynamics of some waders at Kaliszany (1993-1996 and 1999-2001) White bars - maximum count in a pentade, line - average number of birds observed.

- 2016 indiv. (9\%), Dunlin (Calidris alpina) - 971 birds (4\%) and Spotted Redshank (T. erythropus) - 945 indiv. (4\%) were also recorded at Kaliszany. The Wood Sandpiper (T. glareola), Curlew (Numenius arquata), Ruff (Philomachus pugnax) and Green Sandpiper (T. ochropus), each constituting ca 2-3\% of all the waders, were noted as well. The proportion of the remaining species did not exceed $2 \%$. The pattern of autumn migration dynamics is presented for the dominant species in Figure 2.

Oystercatcher (Haematopus ostralegus). In 1994-2000 it was recorded in low numbers. Every year from 1 to 4 birds were noted.

Lapwing (Vanellus vanellus). It was recorded during the whole study period. The autumn migration was characterised by two peaks and was the most intensive in the first pentade of September and at the beginning of October. The studied sandy islets were the resting areas for this species. Most often they were foraging on meadows adjacent to the river. The birds usually arrived from the foraging places at 10.00-12.00 a.m. The largest resting group of Lapwings was observed on 28 Sep. 1999 - 310 indiv.

Golden Plover (Pluvialis apricaria). It was seen on: 29 Aug. 1996 - 2 birds, 12-17 Sep. 1999 - from 1 to 3 birds and 18 Oct. 2001 - 19 indiv.

Grey Plover (Pluvialis squatarola). In total 103 individuals were noted. Recorded in flocks up to 10 birds (8-9 Aug. 2000). The earliest occurrence of migratory Grey Plovers was 22 Jul. 1996 (1 bird), while the latest one - 18 Oct. 2001 (1 indiv.).

Ringed Plover (Charadrius hiaticula). Noted every year, but in low numbers. The study area was the breeding site for this species and some birds observed in July and 
August originated from the local breeding population, however, proportion of these birds was unknown. In October recorded occasionally and this was a period with only two observations: on 7 Oct. 1999 (3 indiv.) and on 27 Oct. 1999 (1 indiv.).

Little Ringed Plover (Charadrius dubius). It was observed from 15 Jul. to 22 Sep. The study area was the breeding site for this species and some birds noted in July and August originated from the local breeding population, however, proportion of these birds was unknown. Recorded most frequently in August and the first half of September. In 2001 this species was not recorded at all.

Woodcock (Scolopax rusticola). Single birds were seen on 21 Aug. 1993, 27 Jul. 1994, 8 Aug. 1994 and 12 Aug. 2000.

Common Snipe (Gallinago gallinago). The only observation in July was on 17 Jul. 1995 - 1 indiv. The regular migration started in the first pentade of August and finished in the end of August. The largest flocks were observed on 20 Aug. 1994 - 26 indiv. and 9 Aug. 2000 - 26 indiv. Two latest records were from 13 Sep. 1999 (1 indiv.) and 7 Oct. 2000 (2 birds).

Black-tailed Godwit (Limosa limosa). Within the whole study period recorded only 18 times (30 indiv.). In July - 20 birds, in August -8 indiv. and in September - 2 birds.

Whimbrel (Numenius phaeopus). Noted every year but in very low numbers. In 1993 - 1 bird, 1994 - 6 indiv., 1995 - 4 indiv., 1996 - 3 indiv., 1999 - 2 indiv., 2000 1 bird and in 2001 - 1 bird. Majority of birds passed above the study area in August. There was only one record from July (30 Jul. 1996) - 2 birds and three observations in September: 3 Sep. 1994 - 1 bird, 4 Sep. 1994 - 1 bird and 2 Sep. 2001 - 1 indiv.

Curlew (Numenius arquata). Regular, but not numerous on migration. Noted between 28 Jul. and 14 Oct. Curlews arrived in small numbers in the third decade of July: the first on 28 Jul. The majority of birds passed the study area in September. Very intensive migration of the species was observed from 17 Aug. to 9 Oct. 2001. As a consequence, during the 2001 season as many as 402 birds (71\% of all Spotted Curlews recorded in the study period) were observed. The highest number of birds (26 indiv.) was seen on 12-13 Sep. 2001.

Spotted Redshank (Tringa erythropus). It was recorded form 23 Jul. to 28 Oct. in the study area. This is one of the species showing the highest variation in number among years. Very intensive migration of the species was noticed from 20 Aug. 2001 to 25 Oct. 2001. The largest group (115 indiv.) was noted on 4 Sep. 2001. Only during the 2001 season there were noted 801 birds (85\% of all Spotted Redshanks recorded in the study period). The most intensive migration took place in the first pentade of September. The last birds were seen on 28 Oct. 1999 and 25 Oct. 2001.

Redshank (Tringa totanus). The first bird was observed on 19 Jul. 1994. The species noted most frequently in August. In the later period recorded only occasionally - only two observations from September: 12 Sep. 2000 (1 indiv.) and 22 Sep. 2001 (8 birds).

Marsh Sandpiper (Tringa stagnatilis). It was observed mainly in August (10 birds in total). In the later period recorded occasionally - two records from September 1 indiv. - 3 Sep. 1999 and 1 bird - 15-16 Sep. 1999.

Greenshank (Tringa nebularia). First birds arrived in small numbers in July. The autumn migration was characterized by two waves. The first peak occurred in mid- 
-August and the second one - at the beginning of September. In October, the number of birds was very low, but they were seen more regularly since then. The largest flock consisted of 73 birds - 5 Sep. 2001. The latest observation of two birds took place on 25 Oct. 2001.

Green Sandpiper (Tringa ochropus). This species was passing in low numbers from 1 to 16 birds. The most intensive passage started in August and finished in the second half of September. The latest observation of a single bird was made on 19 Sep. 2001.

Wood Sandpiper (Tringa glareola). The species was regularly migrating in relatively low numbers. Within the studied period Wood Sandpipers migrated in two waves. The first number increase occurred at the beginning of August. Shortly after this peak, the second increase occurred at the end of August. The most numerous flocks were noted on: 24 Aug. 2001 - 40 indiv. and 6 Aug. 1996 - 28 indiv. The passage finished in mid-September, when groups of up to 6 birds were recorded. The latest observation of a single bird was made on 19 Sep. 1999.

Common Sandpiper (Actitis hypoleucos). During the autumn, the Common Sandpiper was one of the earliest autumn migrant. The count data did not cover the beginning of migration of this species. Within the studied period the majority of birds passed the study area till the end of August. The autumn migration finished in the second half of September. The last birds were recorded on 23 Sep. 2000 (1 indiv.), 23 Sep. 2001 ( 2 indiv.) and 4 Oct. 2000 ( 1 indiv.). The best period of the day to count birds of the species was the evening, when Common Sandpipers were flocking and calling intensively. The biggest recorded flocks of Common Sandpipers were seen on: 3 Aug. 1994 - 50 indiv. and 5 Aug. 1995 - 70 indiv.

Turnstone (Arenaria interpress). Recorded only 5 times: on 23 Aug. 1993 (1 bird), 24 Aug. 1993 (1 bird), 13 Aug. 1994 (1 indiv.), 2 Sep. 1994 (3 indiv.) and 9 Sep. 1994 (1 indiv.).

Knot (Calidris canutus). Small flocks (up to 5 birds) were observed from 27 Aug. to 1 Sept. 1995. The species was also recorded on 4 Sep. 2001 (3 indiv.) and 5 Sep. 2001 (6 birds).

Sanderling (Calidris alba). Recorded 6 times (14 birds). The earliest observation was on 23 Aug. 1993, while the last one - on 6 Oct. 1999 (2 birds in both cases). The largest flock was observed on 5 Sep. 2001 - 5 birds.

Little Stint (Calidris minuta). Recorded every year but in low numbers. The migration started at the beginning of August: 3 Aug. 1994 (2 indiv.) and 3 Aug. 1995 ( 1 indiv.). The majority of birds passed in August and the first half of September. The peak of autumn migration occurred in the first pentade of September: 5 Sep. $2001-$ 19 birds. The latest observation was on 7 Oct. 1999 - 5 birds.

Temminck's Stint (Calidris temminckii). Occurring irregularly, the highest numbers were recorded in the first and third decade of August. The only observation in September took place on 2 Sep. 1994 (1 indiv.). The largest flock was recorded on 25 Aug. 1993 - 10 indiv.

Curlew Sandpiper (Calidris ferruginea). First birds arrived in small numbers in the third decade of July: 23 Jul. 1995 (3 indiv.) and 25 Jul. 1996 (2 indiv.). Most observations came from August. It was found that adults migrated earlier than first-year 
birds. The largest flock was 20 birds -8 Sep. 1994. The last single bird was seen on 2 Oct. 1999.

Dunlin (Calidris alpina). First adult Dunlins arrived in small numbers in the third decade of July: 23 Jul. 1994 (1 indiv.) and 23 Jul. 1995 (1 indiv.). At the beginning of August, the first peak (less numerous) occurred - it consisted of adult birds (max. 31 birds on 6 Aug. 2000). The second peak of passage, comprising mainly young birds, occurred in the second half of September. In October the number of birds decreased and they were observed mainly in low numbers. The latest observations took place on 24 Oct. 2001 (2 indiv.) and 25 Oct. 1999 (1 indiv.).

Broad-billed Sandpiper (Limicola falcinellus). Recorded from 13 Aug. to 1 Sep. only in 1994 (7 birds) and 1995 (1 bird).

Ruff (Philomachus pugnax). The autumn migration started in the third decade of July, the first observations were made on: 20 Jul. 1994 (1 indiv.) and 24 Jul. 1995 ( 1 indiv.). The majority of birds passed the study area in August and the first half of September. The most numerous flock of 38 indiv. was recorded on 5 Sep. 2001. The latest observation of Ruffs was made on 24 Oct. 2001 - 2 birds.

\section{DISCUSSION}

In the study area 27 species of waders were observed out of 57 recorded in Poland (Avifaunistic Commision 2006). In other regions of Poland where migration of waders was monitored, the number of species was higher than in the studied area. On the Baltic coast, Meissner and Sikora (1995) recorded 36 species of waders. Similarly, on the Jeziorsko reservoir 36 species were noted (Janiszewski et al. 1998) and in the San valley - 32 species (Kunysz and Hordowski 1992). On the other hand data from the middle Vistula valley presented by Luniak (1971) related to 29 wader species. Monitoring of waders migration along the middle Vistula near Pawłowice (ca $80 \mathrm{~km}$ from Kaliszany), performed by Kozik (2006), detected only 25 species. Similar number of wader species (26) from the Odra valley was reported by Bocheński et al. (2006).

Only several authors in Polish ornithological literature presented the domination structure in the period of autumn migration (Meissner and Sikora 1995, Mitrus et al. 1998a, Polakowski and Juniewicz 1998, Kruszyk and Zbroński 2002, Kozik 2006). The results in papers cited above are quite similar to these recorded near Kaliszany and presented in this study. All authors underlined the high proportion of the Lapwing. For example in the Bug valley, Mitrus et al. (1998a) recorded the high dominance of this species - almost 50\%. Data presented by Kozik (2006) from the Vistula near Pawłowice were slightly higher $-56 \%$. In the species composition of the middle Vistula valley at Kaliszany, the Lapwing was dominant, with almost half of all waders counted. The analysis of the autumn migration data indicated that the structure of domination recorded at Kaliszany was similar to that observed in the middle Vistula valley at Pawłowice, where the Lapwing and Common Sandpiper dominated. However, in contrast to the data from Pawłowice (Kozik 2006) and most of other regions of Poland (Mitrus et al. 1998a, Polakowski and Juniewicz 1998, Kruszyk and Zbroński 2002), the autumn migration of Wood Sandpipers in our study area was less intensive 
(only $3 \%$ of all recorded waders). In the study area near Kaliszany the proportion of the Common Sandpiper was $16 \%$. The percentage of this species in the dominance structure in the Bug valley was higher - almost 20\% (Mitrus et al. 1998a), but at the Vistula near Pawłowice the proportion was similar to data from Kaliszany - 14\% (Kozik 2006).

In comparison to our study, data presented by Kozik (2006) from the Vistula near Pawłowice are different for a few species. At Kaliszany the higher proportions in the wader's assemblage were recorded for the following species: the Dunlin, Spotted Redshank, Curlew, Green Sandpiper and Curlew Sandpiper. The participation of these species reached 1-4\%, while near Pawłowice it was always below $1 \%$ (from 0.2 to $0.9 \%$ ). Such differences in the domination structure could have been influenced by the longer time of observation at Kaliszany (up to the end of October), as the period of observation at Pawłowice was much shorter (to the end of August). Migration of juveniles of the Curlew Sandpiper, Spotted Redshank, Dunlin, Curlew and Green Sandpiper takes place in September (Meissner and Sikora 1995, Gromadzka 1998, Tomiałojć and Stawarczyk 2003), thus the percentage of these species was much higher at Kaliszany. Moreover, the differences may have been caused by the differences in micro-habitat structure and food availability between these places. For some species, including the Common Sandpiper, time of the day in which counts were done is very important. At Kaliszany the waders were counted in the evening, when Common Sandpipers were flocking and calling intensively.

Analysing a set of species migration patterns it seems that the species turnover can be viewed as a dynamic phenological process, where species sequentially replace others over time at a migration site. Obviously different species have their own periods of migration. In our study area the first migrating species were the Common Sandpiper and Wood Sandpiper while the latest migrants were the Curlew and Dunlin. Migration dynamics of the most numerous species observed in Kaliszany were similar to other regions of Poland. The autumn passage of the Lapwing in Poland consists of several waves, but the main peak falls within October (Tomiałojć and Stawarczyk 2003). The passage dynamics of the Lapwing at Kaliszany showed two peaks: in the first decade of September and at the beginning of October. In the data presented by Kozik (2006) the main peak of Lapwing migration was in August, however author was not monitoring birds in September and at October. The autumn migration pattern of this species seems to be very similar in most of Poland. Our data correspond to studies on the big inland reservoirs: the Turawa reservoir (Stawarczyk et al. 1996), Mietkowski reservoir (Dyrcz et al. 1998) and in the middle Odra valley (Bocheński et al. 2006) - the peak of abundance occurred in the second half of September and in the beginning of October. Similar data with large concentration of Lapwings in October were described for the San valley (Kunysz and Hordowski 1992) and Jeziorsko reservoir (Janiszewski et al. 1998). However, in some regions the migration of the Lapwing started, reached the peak of abundance and finished earlier (Zieliński and Studziński 1996, Kruszyk and Zbroński 2002). The migration peak of this species at the Puck Bay was recorded in July, but on the sea coast birds migrate in a different way in comparison with inland valleys (Meissner and Sikora 1995). 
The phenology of occurrence and migration dynamics of the Common Sandpiper in the middle Vistula valley were quite similar to other places in Poland, with the peak of autumn passage in the second half of July and in the first half of August. Similar patterns of Common Sandpiper migration were recorded in the Bug valley (Mitrus et al. 1998b), Gulf of Gdańsk (Meissner and Sikora 1995), Turawa reservoir (Stawarczyk et al. 1996), Mietkowski reservoir (Dyrcz et al. 1998) and in the middle Vistula valley near Pawłowice (Kozik 2006).

Migration of the Greenshank along the middle Vistula at Kaliszany showed two peaks: in the second half of August and in the first decade of September. A similar pattern was recorded in the middle Odra valley (Bocheński et al. 2006) and in the Gulf of Gdańsk (Meissner and Sikora 1995). The bimodal dynamics is probably caused by migration of different age birds separated in time. Adults migrate earlier than first-year birds.

We showed that the Dunlin had two migration peak: in the first decade of August and in the second half of September. The first small peak illustrated the passage of adult birds, whereas the second concerned migrating juveniles. Contrary to the Gulf of Gdańsk (Meissner and Sikora 1995, Gromadzka 1998) the autumn migration of adult Dunlins in the middle Vistula valley was less intensive than in the case of first-year birds. Similar situation occurred in other inland areas: the Nyski reservoir (Stawarczyk et al. 1996), Lake Rakutowskie (Zieliński and Studziński 1996) and Mietkowski reservoir (Dyrcz et al. 1998).

During the period of autumn migration of the Spotted Redshank the largest assemblages in the Vistula valley near Kaliszany were noted at the beginning of September. The analogical data were presented from the Odra valley, where the highest numbers of birds were observed near Nowa Sól in September (Bocheński et al. 2006). In the middle Vistula valley near Pawłowice single birds were noted from the half of July to the end of August (Kozik 2006). Observations at that place were probably finished before the period of the most intensive migration of this species.

The autumn migration of the Wood Sandpiper in Kaliszany had two waves. The first occurred at the beginning and the second at the end of August. The studies in the Vistula valley near Pawłowice also showed two peaks for this species. A similar situation was recorded in other regions of Poland (Kunysz and Hordowski 1992, Meissner and Sikora 1995, Mitrus et al. 1998c). According to these authors, bimodal dynamics is caused by migration of different age birds separated in time.

The Ringed Plover and Little Ringed Plover were regularly noted in the studied area from July to October, but in lower numbers than in the middle Vistula valley near Pawłowice (Kozik 2006). This situation probably resulted from differences in local breeding populations between these two sites.

The migration dynamics observed at Kaliszany in the Vistula valley were generally similar to other regions of Poland. Small differences in the patterns of migration could depend on weather conditions, food availability or breeding success in different places and studied seasons. While interpreting the collected data the frequency and distribution of counts during the study period should be taken into account. These problems were underlined by many authors (Meissner and Sikora 1995, Mitrus et al. 1998b, Kozik 2006, Bocheński et al. 2006). 
Results of our counts demonstrate a significant autumn movement of waders along the middle Vistula near Kaliszany. However, it was found that waders in the study area do not concentrate in so large numbers as those reported from the Gulf of Gdańsk (Meissner and Sikora 1995, Gromadzka 1998) or dam reservoirs in Śląsk (Stawarczyk et al. 1996, Dyrcz et al. 1998). The middle Vistula is a large, unregulated river with numerous islands, where waders can find many places to rest and feed and thus they may disperse to a great extent. Another characteristic of the middle Vistula is a fact that feeding conditions can be very changeable, greatly depending on the water level. The number of recorded wader species (27) and the number of individuals counted (23 030 birds) indicate that this part of the Vistula valley plays an important role during autumn passage of waders. However, recently we have observed a decline in number of waders during the autumn migration at this place (data unpubl.) as opposed to the 1980s and 1990s, when significantly more waders during one count were seen at Kaliszany. Food conditions have a major influence on the number of waders stopping at a stopover site (Meissner 2007a). The decline in wader numbers at Kaliszany can result at least partly, from changes in habitat quality and prey availability. Organic matter carried by the river may be deposited into sandy islands. Over the last two decades the river become cleaner and much organic matter providing high prey densities subsequently became mineralised (Wójciak pers. comm.).

\section{ACKNOWLEDGEMENTS}

We are grateful to all the colleagues who participated in the fieldwork and especially to the organizers and chiefs of the scientific camps at Kaliszany: Łukasz Bednarz, Tomasz Buczek, Piotr Deptuś, Katarzyna Dylon, Urszula Giedrojć, Marek Keller, Paweł Kołodziejczyk, Jarosław Krogulec, Ludwik Maksalon, Małgorzata Mazur, Michał Miazga, Małgorzata Piotrowska, Michał Piskorski, Robert Rudolf, Jacek Tabor, Piotr Wencel, Janusz Wójciak. The study was supported by Maria Curie-Skłodowska University, University of Life Sciences in Lublin and the Lublin Ornithological Society.

\section{REFERENCES}

Avifaunistic Commision. 2006. List of the national avifauna. http://www.biol.uni.wroc.pl/komfaun

Bocheński M., Czechowski P., Jerzak L. 2006. Migrations of waders (Charadrii) in the middle Odra valley (W Poland). Ring 28, 1: 3-18.

Dyrcz A., Kołodziejczyk P., Martini K., Martini M. 1998. Birds of Mietków Reservoir. Ptaki Śląska 12: $17-80$.

Gromadzka J. 1998. Wader ringing at the Vistula mouth (Baltic coast, Poland) - a summary of the long-term studies. Ring 20, 1-2: 5-20.

Grzywaczewski G., Kołodziejczyk P., Mazur M., Miazga M., Piskorski M. 1998. Report of the ornitological camps in the middle Vistula valley near Kaliszany. Not. Orn. 39, 1: 55-58.

Janiszewski T., Włodarczyk R., Bargiel R., Grzybek J., Kaliński A., Lesner B., Mielczarek S. 1998. Birds of the Jeziorsko reservoir in 1986-1996. Not. Orn. 39, 3: 121-150.

Kondracki J. 2001. Regional geography of Poland. PWN, Warszawa. 
Kozik R. 2006. Autumn migration of waders (Charadrii) in the middle Vistula valley in 2004-2005. Ring 28, 1: 19-31.

Kruszyk R., Zbroński R. 2002. Migration of waders (Charadrii) at the sediment-ponds and floods of coal-mines in Jastrzębie Zdrój. Ring 24, 1: 105-119.

Kunysz P., Hordowski J. 1992. Migration of water-and-marsh birds in the Valley of the middle San (South-eastern Poland). Acta zool. cracov. 35, 2: 285-313.

Luniak M. 1971. Birds of the middle reaches of the Vistula. Acta orn. 13: 17-113.

Meissner W. 2005. Autumn migration of the Broad-billed Sandpiper Limicola falcinellus on the southern Baltic Coast. Ring. \& Migr. 22: 171-176.

Meissner W. 2006. Timing and phenology of Curlew Sandpiper Calidris ferruginea on southward migration through Puck Bay, Poland. International Wader Studies 19: 121-124.

Meissner W. 2007a. Stopover strategy of adult and juvenile Red Knots Calidris c. canutus in the Puck Bay, southern Baltic. Ardea 95: 97-104.

Meissner W. 2007b. Different timing of autumn migration of two Ringed Plover Charadrius hiaticula subspecies through the southern Baltic revealed by biometric analysis. Ring. \& Migr. 23: 129-133.

Meissner W., Huzarski S. 2006. Autumn migration of the Ringed Plover Charadrius hiaticula in the Gulf of Gdansk. Not. Orn. 47, 1: 23-32.

Meissner W., Sikora A. 1995. Spring and autumn migration of waders (Charadrii) on the Hel Peninsula. Not. Orn. 36, 3-4: 205-239.

Meissner W., Strzałkowska M. 2006. Autumn migration dynamics of the Dunlin (Calidris alpina) at the Reda Mouth (southern Baltic). Ring 28, 1: 33-43.

Meissner W., Ściborski M. 2002. Autumn migration of the Bar-tailed Godwit (Limosa lapponica) in the Gulf of Gdansk region. Ring 24, 1: 3-15.

Mitrus C., Kuczborski R., Słupek J. 1998a. Report on ringing and observations of waders at the Bug river (central-eastern Poland) in 1986-1990. Ring 20, 1-2: 73-76.

Mitrus C., Kuczborski R., Słupek J. 1998b. Autumn passage of the Common Sandpiper Actitis hypoleucos in the Bug River valley - dyanamics and biometry. Not. Orn. 39, 1: 13-25.

Mitrus C., Kuczborski R., Słupek J. 1998c. The autumn passage of the Wood Sandpiper (Tringa glareola) in the Bug Valley - dyanamics and biometry. Ring 20, 1-2: 107-116.

Polakowski M., Juniewicz M. 1998. Autumn migration of waders at the sewage treatment plant in Fasty near Biatystok (eastern Poland). Ring 20, 1-2: 59-67.

Stawarczyk T., Grabiński W., Karnaś A. 1996. Migration of Charadriiformes at Nyski and Turawski Reservoir in 1976-94. Ptaki Śląska 11: 39-80.

Ściborski M., Meissner W., Krupa R., Włodarczyk R., Kaczmarek K., Bargiel R., Wojciechowski A., Raniczkowska A., Kozik R., Pietrasik J. 2005. Fieldwork results of wader research stations working in Poland in 2002-2003. Ring 27, 1: 93-99.

Wiehle D., Wilk T., Faber M., Betleja J., Malczyk P. 2002. Avifauna of the upper Vistula River valley - part I. Birds of the Ziemia Oświęcimsko-Zatorska region. Not. Orn. 43, 4: 227-253.

Tomiałojć L., Stawarczyk T. 2003. Avifauna of Poland. Distribution, number and changes. PTTP "pro Natura", Wrocław.

Zieliński M., Studziński S. 1996. Avifauna of the marshland of Btota Rakutowskie near Wtoctawek. Not. Orn. 37, 3-4: 259-300. 